\title{
Contribution of diminished kidney transplant GFR to increased circulating chemokine ligand 27 level
}

\author{
Ahmed Zahran ${ }^{1}$, Ahmed Attia ${ }^{2}$, Holly Mansell ${ }^{3}$ and Ahmed Shoker ${ }^{4,5^{*}}$
}

\begin{abstract}
Background: Inflammatory chemokine ligands (CCLs) play an important role in cardiovascular disease and allograft injury. CCLs may independently associate with diminished estimated glomerular filtration rate (eGFR) in stable renal transplant recipients (RTR).

Methods: Plasma levels of 19 CCLs $(1,2,3,4,5,8,11,13,15,17,21,24,26,27, \operatorname{CXCL5}, 8,10,12$ and 13) were measured in a cohort of 101 RTR. The cohort was divided according to CKD-EPI equation into three groups; group 1: eGFR $\geq 60 \mathrm{ml} / \mathrm{min}$, group 2: eGFR 30-59.9 ml/min and group 3 eGFR $\leq 29.9 \mathrm{ml} / \mathrm{min}$. ANOVA, Krusklwallis, MannWhitney Spearman correlation and regression analysis tests were used to determine association between reduced eGFR and inflammatory CCLs plasma levels measured by multiplex techniques. 20 healthy subjects with eGFR above $90 \mathrm{ml} / \mathrm{min}$ were included as control. Significance was sat at $<0.05$.
\end{abstract}

Results: Levels of CCLs 1, 4, 15, 27, CXCL8 and CXCL10 were significantly different among the four studied groups. Multivariate regression analysis (MVA) between eGFR and all CCLs demonstrated that CCL27 was the only ligand to remain significantly associated with diminished eGFR $\{P=0.021$ and $r=-0.35,(P=0.001)\}$. In a second MVA between CCL 27 and patient's demographics and laboratory variables, diminished eGFR, and elevated PTH, out of the twenty one available variables remained significantly associated with elevated CCL27levels.

Conclusion: Diminished eGFR in stable RTR is associated with elevated plasma levels of CCL27. This association may explain, at least in part, the independent contribution of reduced eGFR to enhanced inflammation in RTR.

Keywords: Chemokines, Renal transplantation, Chemokine ligand 27 (CCL27), eGFR

\section{Background}

Chemokines and their ligands (CCLs) are a family of chemotactic cytokines that have ability to induce migration of different cell types especially those of lymphoid origin [1]. They coordinate leucocyte trafficking [2]. CCLs are expressed in tissues in response to injury or infection [3]. There are four families of chemokines; CCL, CXCL, CX3CL, and CL. Many chemokines can bind to multiple receptors and most receptors bind many chemokines [4].

The role of inflammatory CCLs in kidney dysfunction [5], including transplant injury [6], is widely recognized. These mediators play a pivotal role in acute allograft insult

\footnotetext{
* Correspondence: ahmed.shoker@usask.ca

${ }^{4}$ Department of Medicine, University of Saskatchewan, Saskatoon, SK, Canada ${ }^{5}$ Saskatchewan Transplant Program, St Paul's Hospital, 1702- 20th Street West, Saskatoon, SK S7M 0Z9, Canada

Full list of author information is available at the end of the article
}

$[7,8]$ as well as chronic allograft injury and tissue fibrosis [9-11]. Plasma CCLs levels have been postulated to be biomarkers, which may assist in predicting transplant outcomes [12-17] as well as a therapeutic potential in kidney disease acute and chronic allograft nephropathy [18-20].

Chemokines were found to be associated with kidney function in diabetic kidney disease [21, 22]. Previously, we reported on the elevated plasma levels of CCLs in stable RTR [23].

The debate of the relative contribution of diminished eGFR to heightened inflammation in the renal patient remains unsettled.

We propose that the study of stable renal transplant patients with varying eGFR constitute a reasonable cohort to determine the contribution of diminished GFR to elevated plasma levels of CCLs, independent of other 
known factors. As such, the aim of this work was to characterize which circulating plasma chemokines ligands associated with diminished eGFR.

\section{Methods}

This study included 101 stable renal transplant recipients and 20 healthy persons as a control group. The protocol for this study was approved by ethical committee of this institution. Informed consent was obtained from all participants. All RTR were older than 18 years with stable kidney function defined by no previous hospital admission and no change of serum creatinine more than $10 \%$ for the last 3 months. Patients with acute rejection, CMV disease or BK virus kidney disease diagnosed by a biopsy were excluded. All patients were followed at the Saskatchewan transplant program. Blood samples were collected for detection of CCLs. Multiplexed fluorescent bead-based immunoassay for detection of CCLs was described previously [24].

Nineteen CCLs $(1,2,3,4,5,8,11,13,15,17,21,24$, 26, 27, CXCL5, 8, 10, 12 and 13) were measured.

RTR were divided arbitrary into three groups according eGFR, group 1: eGFR $\geq 60 \mathrm{ml} / \mathrm{min}$, group 2: eGFR $30-59.9 \mathrm{ml} / \mathrm{min}$ and group 3 : eGFR $\leq 29.9 \mathrm{ml} / \mathrm{min}$.

The eGFR was calculated from the following equation: GFR (CKD-EPI) $=141 \mathrm{X} \min (\mathrm{Scr} / \mathrm{k}, 1)^{\alpha} \quad \mathrm{X} \max (\mathrm{Scr} /$ $\mathrm{k}, 1)^{-1.209} \mathrm{X} .993^{\text {Age }} \mathrm{X} 1.018$ [if female] X (1.159 [if black] where $\mathrm{k}=0.7$ if female, $\mathrm{k}=0.9$ if male, $\alpha=-0.329$ if female, $\alpha=-0.411$ if male, $\min =$ minimum of Scr $/ \mathrm{k}$ or 1 and $\max$ $=$ maximum Scr $/ \mathrm{k}$ or $1, \mathrm{Scr}=$ serum creatinine $(\mathrm{mg} / \mathrm{dL})$.

\section{Statistical analysis}

Data were collected and analyzed using SPSS version 22 and excel sheet. Numerical data were presented as mean and standard deviation (SD) or median with $95 \%$ confidence interval as appropriate. Categorical data were presented as number and percentage. ANOVA test was used to compare normally distributed data between more than two numerical groups. For non-normalized data Krusklwallis test was used for comparing more than two groups while Mann-Whitney test was used for comparison between each two groups. Chi square test was used to compare groups with categorical data. Spearman correlation was used to test for association between variables. Univariate and multivariate linear regression analysis were used to detect the independent predictor of eGFR reduction in RTR. $P$ value $<0.05$ was considered significant.

\section{Results}

This study included 101 stable RTR and 20 healthy persons as control group.. Nineteen CCLs were measured. Table 1 showed demographics and laboratory data of the stable RTR. Among the three patient groups, levels of hemoglobin, serum phosphorus, Parathyroid hormone, and urinary albumin creatinine ratio were significantly different. The rest of the twenty one demographic variables tested were similar including age and duration of transplantation.

Table 2 shows comparison between the nineteen CCLs levels. All levels were presented as median and CI because of the wide variation in their respective levels and thus were non-normalized values. Comparison of studied groups showed that CCL1, CCL4, CCL15, CCL27, CXCL8 and CXCL10 were significantly different among the tested groups. Control CCL4, CCL15, CCL27, CXCL8 and CXCL10 levels were significantly lower than that in the three patient's groups. Comparison between each two groups is further illustrated in Table 2. CCL27 was significantly elevated in group 3 compared to groups 1 , 2 while there was no significant difference among groups 1 and 2 as seen in Fig. 1. Spearman correlation between eGFR and CCL27 showed significant negative correlation (Fig. 2).

Table 3 shows the univariate (UVA) and multivariate (MVA) analyses between the tested CCLs and eGFR. The UVA showed that CCL15 and CCL27 was independent associate with eGFR. While in the MVA, CCL27 was the only independent associate with reduced eGFR.

\section{Correlative analysis between CCL27 levels and patient's demographic and laboratory variables}

We further, performed Spearman correlation, and multivariate regression analyses between CCL27 levels and the four demographic variables noticed to be significantly different among the patient groups in addition to eGFR. Table 4 showed significant correlation between CCL27 and hemoglobin, parathyroid hormone, and urinary albumin creatinine ratio and as expected eGFR. Multivariate regression analysis showed similar results while the MVA confirmed the significant association between elevated levels of CCL27 and reduced eGFR and to our surprise the significant relationship between elevated parathyroid hormone and CCL27 levels.

\section{Discussion}

Chemokines are small hormone- like polypeptides which regulate cell trafficking and tissue homing [2]. Structure and biology of Chemokines and their ligands are well covered by extensive reviews [4].

The role of chemokines and cytokines in renal injury is well recognized [5] and others have investigated their roles in RTR [6-11].

Therefore we will limit our discussion to our positive results on the increased CCL 27 levels in the context of diminished GFR. First, our assay measures the human mature total CCL 27 and not any of its fragments as per the supplier communication. 
Table 1 Demographic and laboratory characteristics in the studied patient groups

\begin{tabular}{|c|c|c|c|c|c|}
\hline Variables & $\begin{array}{l}\text { Group } 1 \\
\text { eGFR. } \geq 60 \\
(77.27 \pm 17.07)\end{array}$ & $\begin{array}{l}\text { Group } 2 \\
\text { eGFR } 30-59.9 \\
(46.69 \pm 8.92)\end{array}$ & $\begin{array}{l}\text { Group } 3 \\
\text { eGFR } \leq 29.9 \\
(21.43 \pm 5.81)\end{array}$ & ANOVA / K / Chi ${ }^{2}$ & $P$ \\
\hline Age (Years) & $47.04+15.14$ & $52.10+12.45$ & $50.15+15.04$ & 1.28 & 0.28 \\
\hline \multicolumn{6}{|l|}{ Gender: } \\
\hline M: No (\%) & $17(54.8 \%)$ & $25(50 \%)$ & $16(80 \%)$ & \multirow[t]{2}{*}{$5.4^{\mathrm{a}}$} & \multirow[t]{2}{*}{0.08} \\
\hline F: No (\%) & $14(45.2 \%)$ & $25(50 \%)$ & $4(20 \%)$ & & \\
\hline BMl & $27.23+4.27$ & $29.01+5.43$ & $27.32+5.76$ & 1.5 & 0.23 \\
\hline Tx duration (Years) & $7.48+5.75$ & $6.31+4.20$ & $8.95+3.88$ & 2.4 & 0.09 \\
\hline $\mathrm{SBP}(\mathrm{mmHg})$ & $128.3+12.7$ & $127.1+14.0$ & $134.7+18.3$ & 2.0 & 0.14 \\
\hline $\mathrm{DBP}(\mathrm{mmHg})$ & $77.65+8.55$ & $79.1+11.4$ & $79.3+9.9$ & 0.23 & 0.8 \\
\hline \multicolumn{6}{|l|}{ Dialysis: } \\
\hline $\mathrm{HD}$ & $15(57.7 \%)$ & $22(53.7 \%)$ & $13(72.2 \%)$ & \multirow[t]{2}{*}{$1.8^{\mathrm{a}}$} & \multirow[t]{2}{*}{0.41} \\
\hline PD & $11(42.3 \%)$ & $19(48.3 \%)$ & $5(27.8 \%)$ & & \\
\hline \multicolumn{6}{|l|}{ Donor: } \\
\hline Living & $11(39.3 \%)$ & $20(42.6 \%)$ & $6(30 \%)$ & \multirow[t]{2}{*}{$0.93^{\mathrm{a}}$} & \multirow[t]{2}{*}{0.63} \\
\hline Deceased & $17(60.7 \%)$ & $27(57.4 \%)$ & $14(70 \%)$ & & \\
\hline \multicolumn{6}{|l|}{ Diabetes: } \\
\hline Yes & $9(29 \%)$ & 17 (34\%) & $6(30 \%)$ & \multirow[t]{2}{*}{$0.25^{\mathrm{a}}$} & \multirow[t]{2}{*}{0.88} \\
\hline No & $22(71 \%)$ & $33(66 \%)$ & $14(70 \%)$ & & \\
\hline \multicolumn{6}{|l|}{ Smoking: } \\
\hline Yes & $9(29 \%)$ & $8(16.3 \%)$ & $4(20 \%)$ & \multirow[t]{2}{*}{$1.90^{\mathrm{a}}$} & \multirow[t]{2}{*}{0.39} \\
\hline No & $22(71 \%)$ & 41 (83.7\%) & $16(80 \%)$ & & \\
\hline $\mathrm{HB}(\mathrm{g} / \mathrm{L})$ & $126.6+12.6$ & $125.3+16.9$ & $111.4+15.9$ & 6.9 & 0.002 \\
\hline $\mathrm{Ca}(\mathrm{mmol} / \mathrm{L})$ & $2.36+0.13$ & $2.35+0.17$ & $2.34+0.27$ & 0.04 & 0.95 \\
\hline $\mathrm{PO} 4(\mathrm{mmol} / \mathrm{L})$ & $0.89+0.23$ & $1.0+0.25$ & $1.2+0.31$ & 10.7 & 0.000 \\
\hline iPTH (pg/ml) & $14.76+18.72$ & $9.02+4.99$ & $26.82+28.66$ & $10.03^{b}$ & 0.007 \\
\hline Cholesterol (mmol/L) & $4.47+0.93$ & $4.20+1.30$ & $4.98+1.16$ & 1.8 & 0.17 \\
\hline $\mathrm{TG}(\mathrm{mmol} / \mathrm{L})$ & $1.75+0.72$ & $2.03+1.14$ & $2.19+1.14$ & 1.2 & 0.3 \\
\hline LDL (mmol/L) & $2.37+0.77$ & $2.68+0.99$ & $2.72+0.99$ & 1.3 & 0.28 \\
\hline $\mathrm{HDL}(\mathrm{mmol} / \mathrm{L})$ & $1.31+0.44$ & $1.41+0.44$ & $1.24+0.39$ & 1.3 & 0.29 \\
\hline Albumin (g/L) & $37.37+4.34$ & $38.59+3.65$ & $35.90+5.31$ & 2.9 & 0.06 \\
\hline ACR (mg/mmol) & $26.14+33.81$ & $78.9+123.2$ & $186.5+163.6$ & $17.8^{\mathrm{b}}$ & 0.000 \\
\hline HS CRP (mg/L) & $5.1+7.8$ & $6.8+12.0$ & $6.7+6.2$ & $4.86^{\mathrm{b}}$ & 0.088 \\
\hline
\end{tabular}

K Krusklwallis, eGFR Estimated glomerular filtration rate $M$ Male, F Female, No Number, Tx Transplantation, SBP Systolic blood pressure, DBP Diastolic blood pressure, HD Hemodialysis, PD Peritoneal dialysis, HB Hemoglobin, Ca Calcium, PO4 Phosphorus, iPTH Intact Parathormone, TG Triglyceride, LDL Low density lipoprotein, $H D L$ High density lipoprotein, $A C R$ Albumin creatinine ratio, HS CRP High sensitive $C$ reactive protein ${ }^{\mathrm{a}} \mathrm{Chi}$ square

${ }^{\mathrm{b}}$ Krusklwallis

Secondly, the increased sensitivity limits of the luminex immunoassay have made it possible to quantify extreme levels of circulating chemokines. The validity of these assay have been confirmed by other researchers $[25,26]$. In our previous work we demonstrated elevated levels of most of the studied chemokines in stable RTR compared to control group [23] which may emphasize a state of generalized subclinical inflammation in apparently clinically stable patients. In our study we investigated the role of chemokines in context to eGFR in stable RTR.

It is recognized that CCL27 chemokine is a chemoattractant for cells bearing the CCR 10 receptor and which is found on keratinocytes [27], normal mucosa associated colon epithelium, trachea, mammary glands, retina and cells in the central nervous system [28].

It appears that $\mathrm{T}$ cell helper type 2 cytokines stimulate CCL27 secretion and CCL27 promote T helper type 1- 


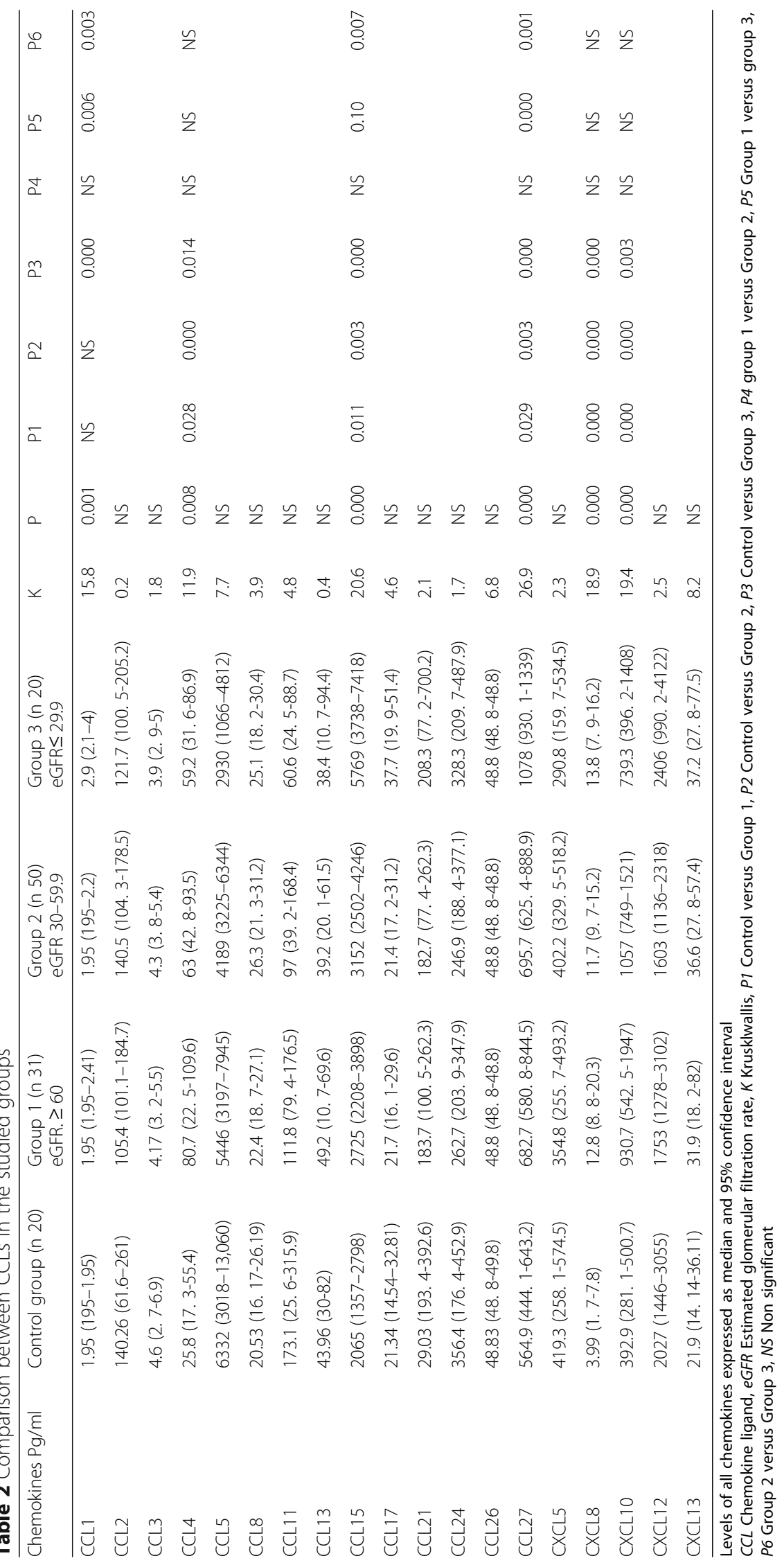




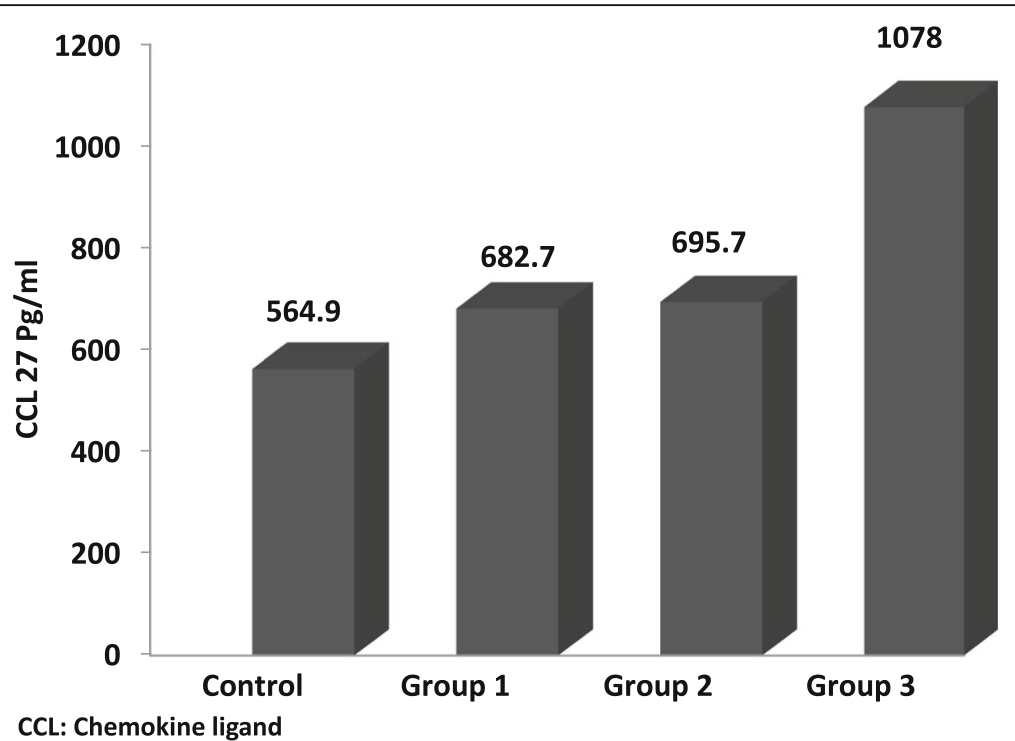

Fig. 1 CCL27 levels in the studied groups

activating antigen presenting cells' It is suggested that CCL27 main function is to recruit lymphocytes to inflammatory tissues particularly the skin $[29,30]$.

CCL27 is also known as cutaneous $\mathrm{T}$ cell- attracting chemokine (CTACK) the only known receptor for CCL27 is CCR 10, which is expressed in normal skin and help to retain memory $\mathrm{T}$ cells homing during inflammatory skin conditions as well as immune surveillance [31].

In the skin, CCL27 is produced by keratinocytes and binds to CCR 10 receptor, characteristic of the majority of
T lymphocytes infiltrating the skin. Specifically, CCL27 helps in lymphocyte adhesion in the skin, leading to pathological inflammatory skin diseases such as psoriasis, atopic dermatitis, mastocytosis [32] and drug induced cutaneous reactions [33]. It has been shown that CCL27 triggers resistance in myeloma cells [34]. Likewise, CCL27 is found in normal nasopharyngeal tissue samples particularly those individuals with seropositive Epstein- Bar virus capsid antigen- specific IgA level (VCA-IgA- positive) and is suggested as a plasma novel biomarker for nasopharyngeal

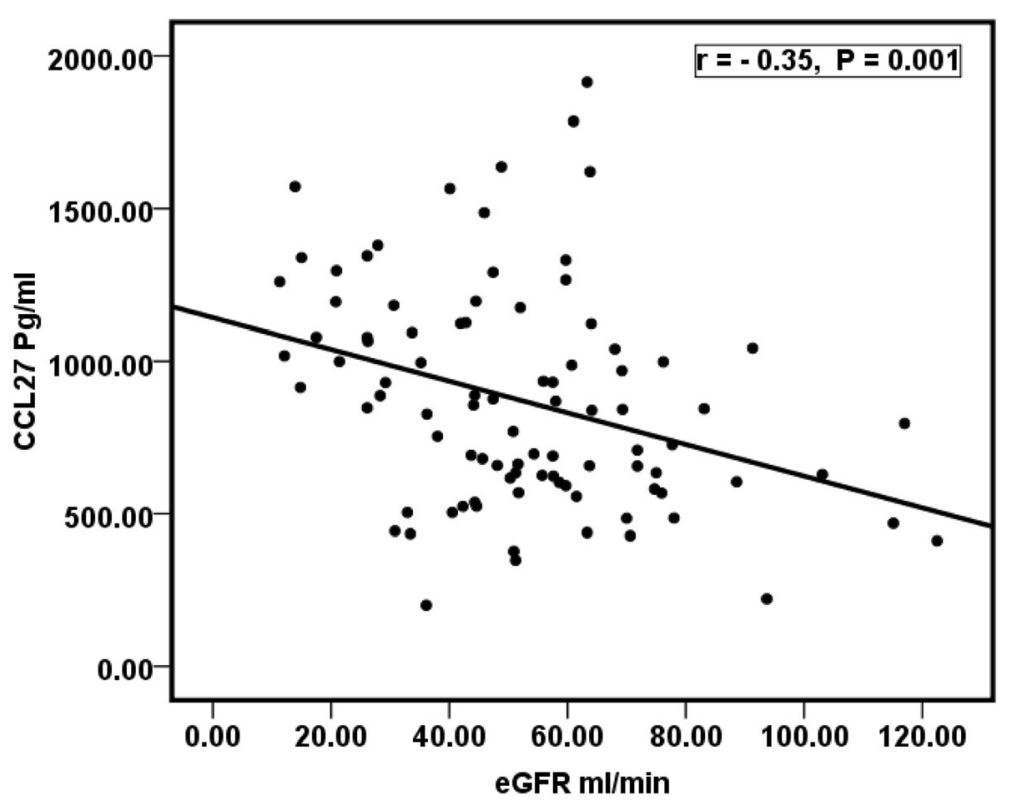

eGFR: Estimated glomerular filtration rate, $\mathrm{CCL}$ : Chemokine ligand

Fig. 2 Spearman correlation between eGFR and CCL27 levels in renal transplant recipients 
Table 3 Univariate and multivariate regression analyses of CCLS independently associated with reduced eGFR in transplant patients

\begin{tabular}{llllll}
\hline Variables & \multicolumn{2}{l}{ Univariate regression } & & \multicolumn{2}{l}{ Multivariate regression } \\
\cline { 2 - 3 } & $\begin{array}{l}\text { Standardized } \\
\text { coefficient }\end{array}$ & $P$ value & & $\begin{array}{l}\text { Standardized } \\
\text { coefficient }\end{array}$ & $P$ value \\
\hline CCL1 & -0.154 & 0.13 & & & \\
CCL4 & 0.138 & 0.19 & & & \\
CCL15 & -0.275 & 0.008 & & -0.095 & 0.461 \\
CCL27 & -0.334 & 0.001 & & -0.300 & 0.021 \\
CXCL8 & 0.089 & 0.43 & & \\
CXCL10 & 0.095 & 0.37 & & \\
\hline
\end{tabular}

CCL Chemokine ligand

carcinoma [35]. More recently, elevated CCL27 levels in patients with multiple sclerosis was observed. These investigators went further to suggest the Skin- Brain connection hypothesis in which the skin is proposed to be involved in MS pathogenesis [30, 36].

On the other hand CCL27 has been suggested to show a better prognosis in patients with cutaneous malignant melanoma [37].

It is not known why CCL27 is elevated in transplant patients with diminished eGFR. It is unlikely to support diminished clearance as a main cause of elevated levels of CCL27 because other CCLs would have been also retained. It is possible that elevated blood CCL27 level is a response to other inflammatory molecules associated with diminished renal function. After all, renal insufficiency is an inflammatory state [38]. Psychophysical stress may enhance CCL27 production [39].

With that in mind we foresee clinical significance of our findings for future studies. For example, it is intriguing to postulate that Skin changes associated with reduced GFR [40] may be attributed to increased CCL27. There is a link between psoriasis and reduction in kidney function $[41,42]$ representing another skin kidney connection. Of further interest, CCL27 was found to be

Table 4 Spearman correlation and multivariate regression analyses between CCL27 levels and patient demographics and laboratory variables

\begin{tabular}{llllll}
\hline Variables & \multicolumn{2}{l}{ Correlation } & & \multicolumn{2}{l}{ Multivariate regression } \\
\cline { 2 - 3 } & rvalue & $P$ value & & $\begin{array}{l}\text { Standardized } \\
\text { coefficient }\end{array}$ & $P$ value \\
\hline HB $(\mathrm{g} / \mathrm{L})$ & -0.30 & 0.005 & & -0.168 & 0.143 \\
iPTH $(\mathrm{pg} / \mathrm{ml})$ & 0.38 & 0.001 & 0.386 & 0.000 \\
Phosphate $(\mathrm{mg} / \mathrm{dl}$ & -0.12 & 0.262 & & \\
ACR $(\mathrm{mg} / \mathrm{mmol})$ & 0.21 & 0.045 & 0.043 & 0.671 \\
eGFR $(\mathrm{ml} / \mathrm{min})$ & -0.35 & 0.001 & & -0.227 & 0.039 \\
\hline
\end{tabular}

$H B$ Hemoglobin, iPTH intact parathyroid hormone, $A C R$ Albumin creatinine ratio, eGFR Estimated glomerular filtration rate. The rest of all other demographic and laboratory variables were not significant highly associated with cutaneous psoriasis [32, 43-45]. Similarly, higher incidence of skin cancer seen in organ transplantation $[46,47]$ may be related to high levels of CCL27. In this context, it is intriguing to postulate the existence of a renal- skin axis similar to that between the skin- brain connections postulated by other researchers [30]. Of further interest, CCR 10, the receptor for CCL27 ligand, is expressed by the podocytes [48] and thus a role for CCL27 in podocytes function and injury in chronic allograft nephropathy is a potential hypothesis for future studies. As such, our finding raises more interesting possibilities such as a role of CCL27 in maintains alloreactive memory by supporting skin memory $\mathrm{T}$ cell population $[49,50]$. If true the skin can be targeted for therapeutic manipulations of CCL27 to reduce inflammation in transplant and kidney diseases. Taken together we raise the intriguing potential of CCL27 as a potential putative marker of those patients who may have progressive decline in kidney function and that it may be a target to protect kidney function.

Elevated PTH is considered a putative uremic toxin in patients with chronic kidney disease. PTH is reported to associate with elevated inflammatory markers such as serum monocyte chemokine protein 1 [51]. Our literature review failed to find a relationship between CCL27 and PTH and thus we cannot speculate on the mechanism by which elevated PTH may enhance production of CCL27 at this stage.

There are limitations to our work. First the clinical relevance of elevated CCL27 needs confirmation by further studies including patients with native kidney diseases. We did not measure tissue levels of CCL27 or its receptor CCR 10. A prospective study of repeated measurement of chemokine and changes in GFR were not done. Finally the cause of decreased renal transplant function such as chronic allograft nephropathy versus other causes of reduced eGFR was not studied in detail. Of note, all our patients were at least stable at the time of study. In addition we stress the fact that there was no significant relationship between CCL27 levels and recipient age, or the duration of transplantation.

\section{Conclusions}

We report on the increased inflammatory chemokine ligands in transplant patients with reduced glomerular filtration rate. In particular, we found elevated blood levels of CCL27 in stable RTR with reduced GFR and raises the possibility of a skin- kidney connection to maintain alloreactivity. Our finding raises the intriguing possibility of targeting the skin as a mean to inhibit CCL27 and thereby decrease renal inflammation in transplant patients and even in native kidney diseases. Future work should test the likelihood that CCL27 can serve as a biological marker for patients who are at excessive risk for progressive decline in kidney function and whether blocking CCL27 may retard progression to kidney failure. 


\section{Abbreviations}

CCLs: Chemokine (C-C motif) ligand; CXCLs: Chemokine (C-X-C motif) ligand; eGFR: Estimated Glomerular Filtration Rate; RTR: Renal Transplant Recipient

\section{Funding}

Slash fund from previous clinical studies.

\section{Availability of data and materials}

Available on request.

\section{Authors' contributions}

AZ participated in statistical analysis, writing of manuscript and in the formatting and submitting of the manuscript. HM participated in the research design. AA participated in the writing of manuscript and formatting of the manuscript for submission. AS participated in the research design, performance of the research, data analysis and in the writing of the manuscript. All authors read and approved the final manuscript.

\section{Ethics approval and consent to participate}

The protocol for this study was approved by ethical committee of Saskatchewan transplant program. Informed consent was obtained from all participants.

\section{Consent for publication}

Yes

\section{Competing interests}

The authors declare that they have no competing interests.

\section{Publisher's Note}

Springer Nature remains neutral with regard to jurisdictional claims in published maps and institutional affiliations.

\section{Author details}

${ }^{1}$ Nephrology Unit, Department of Medicine, Faculty of Medicine, University of Menoufia, Shibin El Kom, Egypt. ${ }^{2}$ National Liver Institute, University of Menoufia, Shibin El Kom, Egypt. ${ }^{3}$ College of Pharmacy and Nutrition, University of Saskatchewan, Saskatoon, SK, Canada. ${ }^{4}$ Department of Medicine, University of Saskatchewan, Saskatoon, SK, Canada. ${ }^{5}$ Saskatchewan Transplant Program, St Paul's Hospital, 1702- 20th Street West, Saskatoon, SK S7M 0Z9, Canada.

Received: 26 April 2018 Accepted: 3 September 2018 Published online: 10 September 2018

\section{References}

1. Segerer S, Nelson PJ, Schlöndorff D. Chemokines, chemokine receptors, and renal disease: from basic science to pathophysiologic and therapeutic studies. J Am Soc Nephrol. 2000;11(1):152-76.

2. Bachelerie $F$, Ben-Baruch A, Burkhardt AM, Combadiere C, Farber JM, Graham GJ, Horuk R, Sparre-Ulrich AH, Locati M, Luster AD, Mantovani A Matsushima K, Murphy PM, Nibbs R, Nomiyama H, Power CA, Proudfoot AE, Rosenkilde MM, Rot A, Sozzani S, Thelen M, Yoshie O, Zlotnik A. International Union of Basic and Clinical Pharmacology. [corrected]. LXXXIX. Update on the extended family of chemokine receptors and introducing a new nomenclature for atypical chemokine receptors. Pharmacol Rev. 2013; 66(1):1-79.

3. Stone MJ, Hayward JA, Huang C, E Huma Z, Sanchez J. Mechanisms of regulation of the chemokine-receptor network. Int J Mol Sci. 2017;18(2):pii: E342.

4. Chung AC, Lan HY. Chemokines in renal injury. J Am Soc Nephrol. 2011; 22(5):802-9.

5. Carrero JJ, Stenvinkel P. Persistent inflammation as a catalyst for other risk factors in chronic kidney disease: a hypothesis proposal. Clin J Am Soc Nephrol. 2009;4(Suppl 1):S49-55.

6. Lo DJ, Weaver TA, Kleiner DE, Mannon RB, Jacobson LM, Becker BN, et al. Chemokines and their receptors in human renal allotransplantation. Transplantation. 2011:91:70-7.

7. Huang H, Xu X, Yao C, Cai M, Qian Y, Wang X, Shi B. Serum levels of CXCR3 ligands predict $\mathrm{T}$ cell-mediated acute rejection after kidney transplantation. Mol Med Rep. 2014;9(1):45-50.
8. Krichen H, Khazen D, Sfar I, Ben Abdallah T, Bardi R, Jendoubi-Ayed S, Makhlouf M, Abderrahim E, Aouadi H, Ayed K, Gorgi Y. Genetic polymorphisms of inflammatory molecules in Tunisian kidney transplantation. Transplant Proc. 2011:43(2):433-6.

9. Dikow R, Becker LE, Schaier M, Waldherr R, Gross ML, Zeier M. In renal transplants with delayed graft function chemokines and chemokine receptor expression predict long-term allograft function. Transplantation. 2010;90:771-6.

10. Zhou HL, Wang YT, Gao T, Wang WG, Wang YS. Distribution and expression of fibroblast-specific protein chemokine CCL21 and chemokine receptor CCR7 in renal allografts. Transplant Proc. 2013;45(2):538-45.

11. Maluf DG, Mas VR, Archer KJ, Yanek K, Gibney EM, King AL, Cotterell A, Fisher RA, Posner MP. Molecular pathways involved in loss of kidney graft function with tubular atrophy and interstitial fibrosis. Mol Med. 2008;14(5-6):276-85.

12. Cravedi $\mathrm{P}$, Heeger PS. Immunologic monitoring in transplantation revisited. Curr Opin Organ Transplant. 2012;17:26-32.

13. Hu H, Kwun J, Aizenstein BD, Knechtle SJ. Noninvasive detection of acute and chronic injuries in human renal transplant by elevation of multiple cytokines/chemokines in urine. Transplantation. 2009;87:1814-20.

14. Ho J, Wiebe C, Gibson IW, Rush DN, Nickerson PW. Immune monitoring of kidney allografts. Am J Kidney Dis. 2012;60(4):629-40.

15. Ho J, Rush DN, Nickerson PW. Urinary biomarkers of renal transplant outcome. Curr Opin Organ Transplant. 2015;20(4):476-81.

16. Rabant M, Amrouche L, Lebreton X, Aulagnon F, Benon A, Sauvaget V, Bonifay R, Morin L, Scemla A, Delville M, Martinez F, Timsit MO, Duong Van Huyen JP, Legendre C, Terzi F, Anglicheau D. Urinary C-X-C motif chemokine 10 independently improves the noninvasive diagnosis of antibody-mediated kidney allograft rejection. J Am Soc Nephrol. 2015; 26(11):2840-51.

17. Dabiri S, Kariminik A, Kennedy D. The role of CXCR3 and its ligands in renal transplant outcome. Eur Cytokine Netw. 2016;27(2):34-40.

18. Vielhauer V, Eis V, Schlöndorff D, Anders HJ. Identifying chemokines as therapeutic targets in renal disease: lessons from antagonist studies and knockout mice. Kidney Blood Press Res. 2004;27(4):226-38.

19. Kakuta Y, Okumi M, Miyagawa S, Tsutahara K, Abe T, Yazawa K, Matsunami K, Otsuka H, Takahara S, Nonomura N. Blocking of CCR5 and CXCR3 suppresses the infiltration of macrophages in acute renal allograft rejection. Transplantation. 2012:93(1):24-31.

20. Xu Y, Zhang Q, Xue W, Zeng S, Zhang Z, Zhang X, Hu X. CXC chemokine receptor 4 (CXCR4) antagonist, a novel pathway to prevent chronic allograft nephropathy. Ann Transplant. 2016;21:728-34.

21. Elewa U, Sanchez-Niño MD, Mahillo-Fernández I, Martin-Cleary C, Belen Sanz A, Perez-Gomez MV, Fernandez-Fernandez B, Ortiz A. Circulating CXCL16 in Diabetic Kidney Disease. Kidney Blood Press Res. 2016;41(5):663-71.

22. Wang G, Lai FM, Chow KM, Kwan BC, Pang WF, Luk CC, Leung CB, Li PK Szeto CC. Urinary mRNA levels of ELR-negative CXC chemokine ligand and extracellular matrix in diabetic nephropathy. Diabetes Metab Res Rev. 2015; 31(7):699-706

23. Elmoselhi $H$, Mansell $H$, Soliman M, Shoker A. Circulating chemokine ligand levels before and after successful kidney transplantation. J Inflamm (Lond). 2016;13:32.

24. Mansell H, Rosaasen N, Dean J, Shoker A. Evidence of enhanced systemic inflammation in stable kidney transplant recipients with low Framingham risk scores. Clin Transpl. 2013;27(4):E391-9.

25. Wong HL, Pfeiffer RM, Fears TR, Vermeulen R, Ji S, Rabkin CS. Reproducibility and correlations of multiplex cytokine levels in asymptomatic persons. Cancer Epidemiol Biomark Prev. 2008;17:3450-60.

26. Kellar KL, Kalwar RR, Dubois KA, Crouse D, Chafin WD, Kane BE. Multiplexed fluorescent bead-based immunoassays for quantitation of human cytokines in serum and culture supernatants. Cytometry. 2001:45:27-36.

27. Fujimoto S, Uratsuji H, Saeki H, Kagami S, Tsunemi Y, Komine M, Tamaki K. CCR4 and CCR10 are expressed on epidermal keratinocytes and are involved in cutaneous immune reaction. Cytokine. 2008;44(1):172-8.

28. Pan J, Kunkel EJ, Gosslar U, Lazarus N, Langdon P, Broadwell K, Vierra MA, Genovese MC, Butcher EC, Soler D. A novel chemokine ligand for CCR10 and CCR3 expressed by epithelial cells in mucosal tissues. J Immunol. 2000; 165(6):2943-9.

29. He Q, Moore TT, Eko FO, Lyn D, Ananaba GA, Martin A, Singh S, James L, Stiles J, Black CM, Igietseme JU. Molecular basis for the potency of IL-10 deficient dendritic cells as a highly efficient APC system for activating Th1 response. J Immunol. 2005;174(8):4860-9. 
30. Blatt NL, Khaiboullin T, Lombardi VC, Rizvanov AA, Khaiboullina SF. The skinbrain connection hypothesis, bringing together CCL27-mediated T-cel activation in the skin and neural cell damage in the adult brain. Front Immunol. 2017;7:683

31. Homey B, Alenius H, Müller A, Soto H, Bowman EP, Yuan W, McEvoy L, Lauerma Al, Assmann T, Bünemann E, Lehto M, Wolff H, Yen D, Marxhausen H, To W, Sedgwick J, Ruzicka T, Lehmann P, Zlotnik A. CCL27-CCR10 interaction regulate T cell mediated skin inflammation. Nat Med. 2002;8(2): 157-65.

32. Nedoszytko B, Sokolowska-Wojdylo M, Ruckemann-Dziurdzinska K, Roszkiewicz J, Nowichi RJ. Chemokines and cytokines network in the pathogenesis of the inflammatory skin disease atopic dermatitis and mastocytosis. Postepy Dermatol Alergol. 2014;31(2):84-91.

33. Tapia B, Padial A, Sánchez-Sabaté E, Alvarez-Ferreira J, Morel E, Blanca M, Bellón T. Involvement of CCL27-CCR10 interactions in drug-induced cutaneous reactions. J Allergy Clin Immunol. 2004;114(2):335-40.

34. Thangavadivel S, Zelle-Rieser C, Olivier A, Postert B, Untergasser G, Kern J, Brunner A, Gunsilius E, Biedermann R, Hajek R, Pour L, Willenbacher W, Greil R, Jöhrer K. CCR10/CCL27 crosstalk contributes to failure of proteasomeinhibitors in multiple myeloma. Oncotarget. 2016;7(48):78605-18.

35. Mao MJ, Xue N, Wang XP, Chi PD, Liu YJ, Huang Q, Dai SQ, Lin WL. Chmokine CCL27 is a novel plasma biomarker for identification the nasopharyngeal carcinoma patients from the Epstein-Barr virus capsid antigen-specific IgA seropositive population. BMC Cancer. 2018;18(1):9.

36. Khaiboullina SF, Gumerova AR, Khafizova IF, Martynova EV, Lombardi VC, Bellusci S, Rizvanov AA. CCL27: novel cytokine with potential role in pathogenesis of multiple sclerosis. Biomed Res Int. 2015;2015:189638.

37. Martinez-Rodriguez M, Thompson AK, Monteagudo C. High CCL27 immunoreactivity in 'supratumoral' epidermis correlates with better prognosis in patients with cutaneous malignant melanoma. J Clin Pathol. 2017;70(1):15-9.

38. Castillo-Rodriguez E, Pizarro-Sanchez S, Sanz AB, Ramos AM, Sanchez-Nino MD, Martin-Cleary C, Femandez-Femandez B, Ortiz A. Inflammatory cytokines as uremic toxins: "Ni son Todos los Que Estan, Ni Estan Todos los Que son". Toxins (Basel). 2017;9(4):pii: E114.

39. Polacchini A, Girardi D, Falco A, Zanotta N, Comar M, De Carlo NA, Tongiorgi E. Distinct CCL2, CCL5, CCL11, CCL27, IL-17, IL-6, BDNF serum profiles correlate to different job-stress outcomes. Neurobiol Stress. 2018;8: 82-91.

40. Rashpa RS, Mahajan VK, Kumar P, Mehta KS, Chauhan PS, Rawat R, Sharma V. Mucocutaneous manifestations in patients with chronic kidney disease: a cross-sectional study. Indian Dermatol Online J. 2018;9(1):20-6.

41. Khan A, Haider I, Ayub M. Poriatic arthritis is an indicator of significant renal damage in patient with psoriasis: an observational and epidemiological study. Int J Inflam. 2017;5217687.

42. Jabbar-Lopez ZK, Weatherhead SC, Reynolds NJ. Kidney disease in moderate-to-severe psoriasis: a critical appraisal. Br J Dermatol. 2016;174(2): 267-70.

43. Garzorz N, Eyerich K. NOS and CCL27: clinical implications for psoriasis and eczema diagnosis and management. Expert Rev Clin Immunol. 2015;11(2): 167-9.

44. Riis JL, Johansen C, Vestergaard C, Bech R, Kragballe K, Iversen L. Kinetics and differential expression of the skin-related chemokines CCL27 and CCL17 in psoriasis, atopic dermatitis and allergic contact dermatitis. Exp Dermatol. 2011;20(10):789-94.

45. Garzorz-Stark N, Lauffer F, Atenhan A, Thomas J, Stark SP, Franz R, Weidinger S, Balato A, Mueller NS, Theis FJ, Ring J, Schmidt-Weber CB, Biedermann T, Eyerich S, Eyerich K. A novel molecular disease classifier for psoriasis and eczema. Exp Dermatol. 2016;25(10):767-74.

46. Garrett GL, Blanc PD, Boscardin J, Lloyd AA, Ahmed RL, Anthony T, Bibee K, Breithaupt $A$, et al. Incidence of and risk factors for skin Cancer in organ transplant recipients in the United States. JAMA Dermatol. 2017;153(3): 296-303.

47. Euvrard S, Kanitakis J, Claudy A. Skin cancers after organ transplantation. N Engl J Med. 2003;348(17):1681-91.

48. Huber TB, Reinhardt HC, Exner M, Burger JA, Kerjaschki D, Saleem MA, Pavenstädt $H$. Expression of functional CCR and CXCR chemokine receptors in podocytes. J Immunol. 2002;168(12):6244-52.

49. Xia M, Hu S, Fu Y, Jin W, Yi Q, Matsui Y, Yang J, McDowell MA, Sarkar S, Kalia $\checkmark$, Xiong $N$. CCR10 regulates balanced maintenance and function of resident regulatory and effector T cells to promote immune homeostasis in the skin. J Allergy Clin Immunol. 2014;134(3):634-44.

50. Davila ML, Fu Y, Uang J, Xiong N. Role of CCR10 and CCL27 in skin resident T cell development and homeostasis. J Immunol. 2016;196(1 Supplement): 137.7.

51. Patel H, Trooskin S, Shapses S, Sun W, Wang X. Serum monocyte chemokine protein-1 levels before and after parathyroidectomy in patients with primary hyperparathyroidism. Endocr Pract. 2014;20(11):1165-9.

\section{Ready to submit your research? Choose BMC and benefit from:}

- fast, convenient online submission

- thorough peer review by experienced researchers in your field

- rapid publication on acceptance

- support for research data, including large and complex data types

- gold Open Access which fosters wider collaboration and increased citations

- maximum visibility for your research: over $100 \mathrm{M}$ website views per year

At BMC, research is always in progress.

Learn more biomedcentral.com/submissions 